\title{
Acaricidal activity of three plants extracts from the central region of Burkina Faso on adult Rhipicephalus (Boophilus) microplus cattle ticks
}

\author{
Anass COULIBALY ${ }^{*}$, Rémy K. BATIONO ${ }^{1}$, Moumouni KOALA ${ }^{2}$, Valérie B. BAZIE ${ }^{1}$, \\ Abel S. BIGUEZOTON ${ }^{3}$, Alassane TOURE ${ }^{3}$, Sébastien ZOUNGRANA ${ }^{3}$, \\ Jean Claude W. OUEDRAOGO ${ }^{2}$, Martine KONE ${ }^{1}$ and Roger C.H.R. NEBIE ${ }^{1}$
${ }^{1}$ Institut de Recherche en Sciences Appliquées et Technologies (IRSAT), Natural Substances Department, 03 BP 7047 Ouagadougou 03, Burkina Faso.
${ }^{2}$ Institut de Recherche en Sciences de la Santé (IRSS), Department of Traditional Medicine-Pharmacopoeia and Pharmacy (MEPHATRA / PH), 03 BP 7047 Ouagadougou 03 Burkina Faso.
${ }^{3}$ Centre International de Recherche-Développement sur l'elevage en zone Subhumide (CIRDES), Acarology service, 01 BP 451 Bobo-Dioulasso 01, Burkina Faso.
*Corresponding author; E-mail: anass.coulibaly@gmail.com; Tel :(00226) 76407287 / 70569701

\begin{abstract}
Rhipicephalus (Boophilus) microplus is the most important and harmful tick species in the livestock sector in Burkina Faso today. This tick has developed resistance to most classes of synthetic acaricides. The objective of this work is to assess the efficiency of plant extracts on this tick to find an alternative. Thus, the acaricidal activity of hydroethanolic and hexanic extracts of Ocimum americanum .L, Ocimum gratissimum .L and Laggera oloptera (DC) Adams was evaluated on adults of this tick by the adult immersion method. The mortality, the inhibition of the laying, the hatching rate, and the effectiveness of each extract have been evaluated with concentrations at $100 \mathrm{mg} / \mathrm{mL}$ and at $200 \mathrm{mg} / \mathrm{mL}$, respectively. The best mortality rate was $56 \%$, with the hydroethanolic extract of L. oloptera at $200 \mathrm{mg} / \mathrm{mL}$. The hydroethanolic extract of O. gratissimum was most effective with the best rates of egg inhibition and hatching rates at $200 \mathrm{mg} / \mathrm{mL}$. The results of this study could be used for the development of new bio-acaricide formulations to fight against the tick R. (Boophilus) microplus effectively.
\end{abstract}

(C) 2020 International Formulae Group. All rights reserved.

Keywords: Ticks, O. gratissimum, O. americanum, Laggera oloptera, phytochemical screening

\section{INTRODUCTION}

In West Africa, Rhipicephalus (Boophilus) microplus is the most harmful tick species in the livestock sector. It is a vector for the transmission of infectious agents to host animals and therefore contributes to decrease meat and milk production (Toure et al., 2012; Grisi et al., 2014). In Burkina Faso, the control of this tick is mainly based on the use of synthetic acaricides, mainly based on deltamethrin, flumetrine, and amitraz. However, the use of this means of control has led to the rapid development of resistance to the active ingredient (Adehan et al., 2016; Aca et al., 2017). Each time ticks survive an application of insecticide, they transmit genetic information to the following generations on the survival method faced with this product 
(Furlong et al., 2004). To adjust this problem of resistance to synthetic acaricides, research is increasingly focused on plant extracts. Thus, a study conducted by Hema (2018) in Burkina Faso, on the acaricidal properties of the hexanic extracts of Ageratum conizoides, Cymbopogon giganteus, Laggera aurita, and Lippia multiflora showed $100 \%$ larval mortality on the $R$. (B.) microplus tick.

Similarly, other studies have shown the effectiveness of plant extracts on this tick in Benin (Adehan et al., 2016), in Brazil (Silva et al., 2017; Politi et al., 2019) in India ( Kumar et al., 2012) in New Caledonia (Lebouvier et al., 2013). To find new sources of natural acaricides, we were interested in three aromatic plants from Burkina Faso (Ocimum gratissimum, Oсітит americanum, and Laggera oloptera) whose biological activities have been reported in numerous works including their insecticidal properties (Nébié, 2006; Ouédraogo et al., 2016; Tia et al., 2019). The present study, therefore, aimed at assessing the acaricide efficacy of the extracts of these three plants on adults of the tick $R$. (B.) Microplus to find an alternative to the synthetic acaricides used in the field.

\section{MATERIALS AND METHODS Plant material}

The plant material consisted of the aerial parts (stems, leaves, and flowers) of Ocimum gratissimum, Ocimum americanum, and Laggera oloptera. The plants were harvested in September 2017 in the central region of Burkina Faso $\left(12^{\circ} 25^{\prime} 17^{\prime \prime}\right.$ North and $1^{\circ} 29^{\prime} 14^{\prime \prime}$ West). Plant material was dried for two weeks in the laboratory of the Natural Substances Department of the Research Institute for Applied Sciences and Technologies (IRSAT) out of the sun. After drying, the plant material was pulverized using a mechanical grinder.

\section{R. (B.) microplus tick strain}

The tick strains used in our study were made up of adult females. They came from Kimini $\left(10^{\circ} 06^{\prime} 24\right.$ "North and $4^{\circ} 466^{\prime} 50^{\prime \prime}$ West) and have been identified in the laboratory of the International Center for Research and
Development on Livestock in the Subhumid zone (ICRDLS). These ticks were kept under control $\left(27-28{ }^{\circ} \mathrm{C}, \mathrm{RH} 70-80 \%\right.$, photoperiod $12 \mathrm{~h} / 12$ ) in an oven. The eggs laid by these females were hatched for about four weeks to obtain larvae. These larvae were used to infest single oxen to get new adult females after 20 25 days. These were used to carry out acaricide tests.

\section{Preparation of plant extracts}

The extraction protocol consisted of macerating twice successively for (03) hours, $250 \mathrm{~g}$ of powder from each plant in an ethanol/water mixture (80:20) for the hydroethanolic extracts, and in hexane for hexanic extracts. The residue obtained was extracted again for 16 hours before filtration. All filtrates obtained are combined and evaporated to dryness under reduced pressure using a rotary evaporator. Finally, the reduced hydroethanolic extract obtained was freeze-dried while the hexanic extract was placed in an oven to evaporate the extraction solvent.

\section{Phytochemical screening}

Each raw extract was subjected to phytochemical screening. Tannins, flavonoids, alkaloids, saponins, and triterpenes were searched for on the various extracts using standard procedures as described in the literature (Wagner and Bladt., 1996; Békro et al., 2007; Ramde-Tiendrebeogo et al., 2019; Nitiema et al., 2020).

\section{Adult immersion test}

Groups of 10 adult females of Rhipicephalus (Boophilus) microplus, randomly selected, were immersed for $5 \mathrm{~min}$ in Petri dishes $(5.5 \mathrm{~cm}$ in diameter, $1.5 \mathrm{~cm}$ in height) containing $10.0 \mathrm{~mL}$ of ethanolic or hexanic extract. These extracts were prepared in a solution containing $2 \%$ of tween 20 at the concentrations of $100 \mathrm{mg} / \mathrm{mL}$ and $200 \mathrm{mg} / \mathrm{mL}$ $(\mathrm{m} / \mathrm{v})$. The $2 \%(\mathrm{v} / \mathrm{v})$ tween 20 solution was used as a negative control. The ticks were then removed from the treatment solution, dried, and distributed individually in sterile Petri dishes. The boxes containing the treated ticks 
were then incubated at $27-28{ }^{\circ} \mathrm{C}$ and $70-80 \%$ relative humidity. After two weeks of incubation, the tick death rate and the rate of inhibition of egg-laying were determined according to the equations of Sabatini et al. (2001):

Mortality Rate $\quad(\mathrm{MR})=$
$\begin{aligned} & \text { Number of dead ticks } \\ & \text { Number of ticks treated }\end{aligned} \times 100$
Laying Index $(\mathrm{LI})=$
weight of laid eggs $(\mathrm{g}) /$ weight of females $(\mathrm{g})$

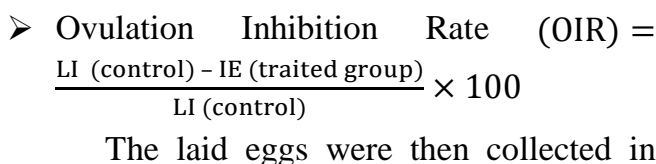
small boxes, weighed and incubated in the oven under the same conditions as before for about four weeks. At the end of the fourth week, the larval hatching rate was estimated by counting the larvae using a stereo-microscope. The efficacy of the extracts was calculated according to the equations proposed by Drummond et al. (1973):

- Hatching $\frac{\text { Number of eggs hatched }}{\text { Total number of eggs }} \times 100$

- Reproductive efficiency(RE) $=$ $\frac{\text { weight of laid eggs }(\mathrm{g}) \times \mathrm{TE} \times 20,000}{\text { Weight of females }(\mathrm{g})}$

- Efficiency of Extracts(EE) = $\frac{\text { ER (control) - ER (traited group) }}{\text { ER (control) }} \times 100$

*: number of larvae obtained for $1.0 \mathrm{~g}$ of eggs (number obtained experimentally)

\section{Statistical analysis}

Statistical analysis was done by XLSTAT software. The data were processed and subjected to a report of variance (ANOVA). The differences between the means were determined by the Tukey test at a significance level of 5\%. The lethal concentration to eliminate $50 \%\left(\mathrm{LC}_{50}\right)$ of adult ticks for the extract that caused more than 50\% mortality and its $95 \%$ confidence interval (CI) were determined by probit analysis.

\section{RESULTS}

\section{Mortality rate and rate of inhibition of laying}

The direct effect of the different extracts on adults of the tick $R$. (B.) microplus shows mortality rates ranging from zero (control group) to $56 \%$ (group treated at $200 \mathrm{mg} / \mathrm{mL}$ ) for hydro-ethanolic extracts . The lethal concentration, which eliminates $50 \%$ ( $\left.\mathrm{LC}_{50}\right)$ of adult females, is obtained only with the hydroethanolic extract of L. oloptera, i.e., 197 $\mathrm{mg} / \mathrm{mL}$. For hexanic extracts, mortality rates range from zero (control group) to over 33\% (group treated at $200 \mathrm{mg} / \mathrm{mL}$ ).

Concerning the rates of inhibition of the laying, the values go from zero (control group) to more than $63 \%$ (group treated with 200 $\mathrm{mg} / \mathrm{mL}$ ) for hydro-ethanolic extracts. As for the hexanic extracts, they inhibit egg-laying from zero (control group) to more than $43 \%$ (group treated with $200 \mathrm{mg} / \mathrm{mL}$ ). The results are reported in Tables 1 and 2.

\section{The efficiency of the extracts on the hatching rate}

Larval hatch rates vary from $100 \%$ (control group) to 24\% (group treated at 200 $\mathrm{mg} / \mathrm{mL}$ ) and from $100 \%$ (control group) to $58 \%$, respectively (group treated at 200 $\mathrm{mg} / \mathrm{mL}$ ) for hydro-alcoholic and hexanic extracts. Regarding the overall efficacy of the extracts, the values vary respectively from zero (control group) to 93\% (group treated with 200 $\mathrm{mg} / \mathrm{mL}$ ) and from $0 \%$ (control group) to more than $65 \%$ (group treated with $200 \mathrm{mg} / \mathrm{mL}$ ) for hydroalcoholic and hexane extracts (Tables 3 and 4).

\section{Phytochemical screening of plant extracts}

The results obtained during phytochemical screening (Table 5) mainly show the presence of tannins, coumarins, alkaloids, and flavonoids in hydro-ethanolic extracts. For hexanic extracts, the main chemical groups found are terpenes and sterols. 
Table 1: Mortality rate as a function of extract concentration.

\begin{tabular}{lllll}
\hline EXTRACTS & \multicolumn{3}{c}{ Mortality rate (\%) } \\
\cline { 2 - 5 } & & Control & $\mathbf{1 0 0} \mathbf{~ m g / m L}$ & $\mathbf{2 0 0} \mathbf{~ m g / \mathbf { m L }}$ \\
\hline Hydro-ethanolic & OA & 0 & 0 & 0 \\
extracts & OG & 0 & $13.33 \pm 0.97^{(\mathbf{b})}$ & $30.00 \pm 0.66^{\text {(a) }}$ \\
& LO & $0^{(\mathrm{C})}$ & $36.6 \pm 0.76^{\text {(a) }}$ & $56.00 \pm 1.14^{\text {(a) }}$ \\
\hline Hexanic extracts & OA & 0 & 0 & 0 \\
& OG & 0 & 0 & 0 \\
& LO & $0^{(\mathrm{C})}$ & $16.66 \pm 8.94^{\text {(b) }}$ & $33.33 \pm 7.14^{\text {(a) }}$ \\
\hline
\end{tabular}

Identical letters in the same column indicate identical statistical groups. The different letters show different statistical groups; OA: Ocimum americanum, $\boldsymbol{O G}$ : Ocimum gratissimum; LO: Laggera oloptera.

Table 2: Ovulation Inhibition Rate (OIR) as a function of the concentration of extract.

\begin{tabular}{|c|c|c|c|c|}
\hline \multirow[b]{2}{*}{ EXTRACTS } & & \multicolumn{3}{|c|}{ Ovulation Inhibition Rate (\%) } \\
\hline & & Control & $100 \mathrm{mg} / \mathrm{mL}$ & $200 \mathrm{mg} / \mathrm{mL}$ \\
\hline Hydro-ethanolic & $\mathrm{OA}$ & $0^{(\mathbf{C})}$ & $24.29 \pm 4.93^{(\mathrm{a})}$ & $36.76 \pm 5.16^{(b)}$ \\
\hline \multirow{2}{*}{ Extracts } & OG & $0^{(\mathbf{C})}$ & $50.21 \pm 5.06^{(\mathrm{a})}$ & $63.32 \pm 10.21^{(\mathbf{a})}$ \\
\hline & LO & $0^{(\mathbf{C})}$ & $46.57 \pm 7.66^{(\mathbf{a})}$ & $60.88 \pm 11.96^{\text {(a) }}$ \\
\hline \multirow{3}{*}{$\begin{array}{l}\text { Hexanic } \\
\text { extracts }\end{array}$} & $\mathrm{OA}$ & $0^{(\mathbf{C})}$ & $22.36 \pm 7.01^{(\mathbf{b})}$ & $36.09 \pm 1.44^{\text {(a) }}$ \\
\hline & OG & $0^{(\mathbf{C})}$ & $20.90 \pm 2.25^{\text {(a) }}$ & $23.87 \pm 3.85^{\text {(a) }}$ \\
\hline & LO & $0^{(\mathbf{C})}$ & $26.32 \pm 7.58^{(\mathbf{b})}$ & $43.17 \pm 1.77^{\text {(a) }}$ \\
\hline
\end{tabular}

Identical letters in the same column indicate identical statistical groups. The different letters show different statistical groups; OA: Ocimum americanum, OG: Ocimum gratissimum; LO: Laggera oloptera.

Table 3: Egg hatching rate as a function of extract concentration.

\begin{tabular}{|c|c|c|c|c|}
\hline \multirow[b]{2}{*}{ EXTRACTS } & & \multicolumn{3}{|c|}{ Egg hatching rate $(\%)$} \\
\hline & & Control & 100 mg/mL & $200 \mathrm{mg} / \mathrm{mL}$ \\
\hline Hydro-ethanolic & $\mathrm{OA}$ & Témoin & $94.27 \pm 0.25^{(\mathbf{a})}$ & $90.17 \pm 2.26^{(\mathbf{a}}$ \\
\hline \multirow[t]{2}{*}{ Extracts } & OG & $100^{\text {(a) }}$ & $72 \pm 8.71^{(\mathrm{d})}$ & $24 \pm 11.13^{(\mathrm{d})}$ \\
\hline & LO & $100^{\text {(a) }}$ & $94 \pm 2^{(\mathbf{a})}$ & $91.3 \pm 7.02^{(\mathbf{a})}$ \\
\hline Hexanic & $\overline{\mathrm{OA}}$ & $100^{\text {(a) }}$ & $98.67 \pm 1.15^{(a)}$ & $92.67 \pm 4.16^{(\mathbf{a}}$ \\
\hline \multirow[t]{2}{*}{ Extracts } & OG & $100^{\text {(a) }}$ & $76 \pm 8^{(\mathbf{b})}$ & $63.33 \pm 5.03^{(c)}$ \\
\hline & LO & $100^{\text {(a) }}$ & $74 \pm 12.16^{(\mathbf{b})}$ & $58.66 \pm 5.03^{(\mathrm{c})}$ \\
\hline
\end{tabular}

Identical letters in the same column indicate identical statistical groups. The different letters show different statistical groups; $\boldsymbol{O A}$ : Ocimum americanum, $\boldsymbol{O G}$ : Ocimum gratissimum; LO: Laggera oloptera. 
Table 4: Efficiency of extracts as a function of concentration.

\begin{tabular}{|c|c|c|c|c|}
\hline \multirow[b]{2}{*}{ EXTRACTS } & & \multicolumn{3}{|c|}{ Efficiency of extracts (\%) } \\
\hline & & Control & $100 \mathrm{mg} / \mathrm{mL}$ & $200 \mathrm{mg} / \mathrm{mL}$ \\
\hline Hydro-ethanolic & $\mathrm{OA}$ & $0^{(\mathbf{b})}$ & $67.15 \pm 5.21^{(a)}$ & $79.62 \pm 8.96^{(\mathbf{a})}$ \\
\hline \multirow[t]{3}{*}{ Extracts } & OG & $0^{(\mathbf{b})}$ & $53.28 \pm 3.43^{(b)}$ & $93.90 \pm 3.74$ (a) \\
\hline & LO & $0^{(\mathbf{b})}$ & $46.57 \pm 7.66^{(\mathbf{b})}$ & $62.58 \pm 14.87^{(a)}$ \\
\hline & $\mathrm{OA}$ & $0^{(\mathbf{b})}$ & $38.79 \pm 7.07^{(\mathbf{b})}$ & $65.92 \pm 8.12^{(\mathrm{a})}$ \\
\hline \multirow{2}{*}{$\begin{array}{l}\text { Hexanic } \\
\text { Extracts }\end{array}$} & OG & $0^{(\mathbf{b})}$ & $26.29 \pm 13.65^{(\mathbf{b})}$ & $59.00 \pm 30.13^{(\mathrm{a})}$ \\
\hline & LO & $0^{(\mathbf{b})}$ & $22.79 \pm 4.19^{(\mathbf{b})}$ & $41.27 \pm 5.22^{(\mathbf{a})}$ \\
\hline
\end{tabular}

Identical letters in the same column indicate identical statistical groups. The different letters show different statistical groups; $\boldsymbol{O A}$ : Ocimum americanum, $\boldsymbol{O G}$ : Ocimum gratissimum; LO: Laggera olpotera.

Table 5: Results of phytochemical assays.

\begin{tabular}{llllllll}
\hline \multirow{2}{*}{ Extraits } & \multicolumn{7}{c}{ Secondary metabolites } \\
\cline { 2 - 7 } & Tannins & alkaloids & Flavonoids & Saponins & $\begin{array}{c}\text { Sterols and } \\
\text { terpenes }\end{array}$ & Quinones & Coumarins \\
\hline OA HA & + & + & + & - & - & - & + \\
OG HA & + & + & + & - & - & - & + \\
LOHA $_{\text {HA }}$ & + & + & + & - & + & - & + \\
OA $_{\text {Hex }}$ & - & - & - & - & - & - & - \\
OG $_{\text {Hex }}$ & - & - & - & - & + & - & - \\
LOHex & - & - & - & - & + & - & - \\
\hline
\end{tabular}

OA:Ocimum americanum; OG: Ocimum gratissimum; LA: Laggera olopera; HA: Hydro-alcoholic, Hex: Hexanic; sign +: presence of compound; sign - : Absence of compound.

\section{DISCUSSION}

The parameters measured during this study were: the rate of tick death, the percentage of inhibition of egg-laying, the rate of hatching, and the efficiency of the extracts.

The results showed cases of mortality, especially with the hydro-ethanolic extracts of $O$. gratissimum and L. oloptera. Indeed, $O$. gratissimum and L. oloptera respectively caused maximum mortality rates of $30 \%$ and $56 \%$ at the concentration of $200 \mathrm{mg} / \mathrm{mL}$ with an $\mathrm{LC}_{50}$ of $197 \mathrm{mg} / \mathrm{mL}$ for L. oloptera. These values are low compared to those obtained with the methanolic extract of Atropa belladonna, which showed a mortality rate of $100 \%$ at 200 $\mathrm{mg} / \mathrm{mL}$ and an $\mathrm{LC}_{50}$ of $68.75 \mathrm{mg} / \mathrm{mL}$ (Godara et al., 2014). Similarly, a mortality rate of up to $100 \%$ was obtained with the hydro-ethanolic extract of Murraya koenigii at $100 \mathrm{mg} / \mathrm{mL}$ with an $\mathrm{LC}_{50}$ of $29.7 \mathrm{mg} / \mathrm{mL}$ (Singh et al., 2015). Finally, Piper nigrum fruit extracts have caused mortalities ranging from 12.5 to $95.8 \%$ and those from Piper longum from 29.2 to $87.5 \%$ at the same concentration. This result shows that the effect of the extracts is more linked to the plant species than to the nature of the extraction solvent.

The rate of inhibition of egg-laying varied from zero for the controls to $60.88 \%$ and $63.32 \%$, respectively, for $O$. gratissimum and L. oloptera at $200 \mathrm{mg} / \mathrm{mL}$. It shows that the quantities of eggs laid in the ticks treated decreased significantly $(\mathrm{P}<0.05)$ compared to the controls. These results corroborate with those of Godara et al. (2014) who also found a $44.2 \%$ reduction in egg-laying with the methanolic extract of Atropa belladonna at 200 $\mathrm{mg} / \mathrm{mL}$. Similarly, another study showed more significant inhibitions of egg-laying of $96.9 \%$ and $89.3 \%$ at $200 \mathrm{mg} / \mathrm{mL}$, respectively, with the ethanolic extract of Piper nigrum and Piper longum (Godara et al., 2018). 
Relative to hatching rates for laid eggs, O. gratissimum had a maximum value of $24 \%$ and L. oloptera, $91.3 \%$ at the concentration of $200 \mathrm{mg} / \mathrm{mL}$. These results are in agreement with those of Godara et al. (2014), who achieved $100 \%$ inhibition of egg hatching with the methanolic extract of Atropa belladonna at $100 \mathrm{mg} / \mathrm{mL}$. Likewise, Parveen et al. (2014) showed $100 \%$ inhibition with the ethanolic extract of Artemisia absinthium at only 50 $\mathrm{mg} / \mathrm{mL}$.

Finally, the maximum efficiency values obtained by $O$. gratissimum and by L. oloptera are $93.90 \%$ and $62.58 \%$ at the concentration of $200 \mathrm{mg} / \mathrm{mL}$, respectively. Politi et al. (2012) obtained a lower maximum efficiency value $(42.45 \%)$ with the ethanolic extract of the aerial parts of Tagetes patula at $200 \mathrm{mg} / \mathrm{mL}$. Similarly, Broglio-Micheletti et al. (2009) obtained efficiency values of $18.35 \%$ with the ethanolic extract of leaves of Cymbopogon citratus and $59.24 \%$ for the ethanolic extract of flowers of Syzygium malaccensis at the same concentration. However, Conceição et al. (2017) achieved an efficiency of up to $90 \%$ with the ethanolic extract of Ocotea aciphylla at only $50 \mathrm{mg} / \mathrm{mL}$.

As for the hexanic extracts, the best results were obtained by L. oloptera at 200 $\mathrm{mg} / \mathrm{mL}$. Indeed, cases of mortality have been noted only with this extract, with a maximum value of $33.33 \%$. This value is lower than that obtained by Castro et al. (2014), who have shown mortality of more than $95 \%$ at 150 $\mathrm{mg} / \mathrm{mL}$ with Acmella oleracea hexanic extract. The maximum rate of inhibition of spawning recorded was $43.17 \%$. This rate is lower than that obtained by Santos et al. (2018), which is $100 \%$ at $200 \mathrm{mg} / \mathrm{mL}$ with the hexanic extract of Digitaria insularis leaves. Similarly, other studies show that the hexanic extracts of Ageratum Conizoides (Hema et al., 2018) and the leaves of Neoglaziovia variegata (Dantas et al., 2015) caused inhibition of egg-laying of $60 \%$ and $94.1 \%$ respectively at $200 \mathrm{mg} / \mathrm{mL}$. As for hatching rates, the maximum value was $58.66 \%$. However, Lippia multiflora hexanic extract has shown an inhibition rate below this value, which is $51 \%$ (Hema et al., 2018). The leaves of Neoglaziovia variegata also showed a 99.8\% higher hatching rate (Dantas et al., 2015). Finally, the overall efficiency obtained was $41.27 \%$ at $200 \mathrm{mg} / \mathrm{mL}$. This value is lower than that obtained by Dantas et al. (2015), which was $99.8 \%$ with the hexanic extract of the leaves of Neoglaziovia variegata.

The phytochemical screening performed on the extracts of the three plants essentially reveals the presence of flavonoids, alkaloids, and tannins for hydro-alcoholic extracts and sterols and terpenes for hexanic extracts. In addition, numerous studies have shown that the acaricidal activity of plant extracts is linked to its composition as secondary metabolites. Indeed, the acaricidal activity of the ethanolic extract of Tagetes gracilis has been attributed to the presence of flavonoids (Abdala et al., 2003). Likewise, the flavonoids could be responsible for the acaricidal activity of the ethanolic extract of Tagetes maxima (Parejo et al., 2004). Godara et al. (2014) also reported that the alkaloids are implicated in the acaricide activity observed by the ethanolic extract of Atropa belladonna. Coumarins are known for their repulsive action against flies and ticks (Emilie, 2011). Finally, it has been shown that tannins are responsible for the acaricidal activity observed with extracts of Acacia pennatula, Piscidia piscipula, Leucaena leucocephala and Lysiloma latisiliquum (Fernandes-Salas et al., 2011). The acaricide activity followed by the different extracts could therefore be linked to the presence of these chemical constituents. This activity was more pronounced with hydroalcoholic extracts than hexanic ones. This could be explained by the fact that it is much more linked to polar than nonpolar compounds.

Some extracts did not cause direct mortality on the $R$. (B.) Microplus tick despite the presence of secondary metabolites. According to Furlong (2000), this would probably be explained by the fact that ticks generally develop different survival mechanisms in the face of acaricides: such as reducing the penetration rate of the product by modifying the external coat, changes in metabolism, storage and excretion of acaricides and changes in the site of action of acaricides. 


\section{Conclusion}

In this study, we evaluated the acaricidal activity of the hydro-alcoholic and hexanic extracts of $O$. americanum, $O$. gratissimum, and L. oloptera on adults of the tick $R$. (B.) microplus. The hydro-alcoholic extracts were the most active, and among these, that of $O$. gratissimum and L. oloptera were the most remarkable. The acaricide activity thus observed is mainly due to the presence of secondary metabolites such as tannins, alkaloids and flavonoids. The results of this study could, therefore, be used to develop new bio-acaricide formulations effective for the control of the $R$. (B.) microplus tick in Burkina Faso. However, it would be interesting to assess the toxicity of the two essential oils beforehand.

\section{COMPETING INTERESTS}

The authors declare that there is no competing interest.

\section{AUTHORS' CONTRIBUTIONS}

This work was carried out in collaboration with all authors. Authors AC and MK designed the study and wrote the protocols. Authors AC, MK, AB, AT, and SZ conducted experimentation and statistical analysis. Author AC wrote the first draft of the manuscript. Authors RB, MK, and VB interpreted the results and reviewed the manuscript. Authors JCO, MKONE, and RN managed the study and designed the journal. All authors read and approved the final manuscript.

\section{Acknowledgments}

Authors thank the competitive national fund of Burkina Faso for the financial support, which made it possible to carry out this study.

\section{REFERENCES}

Abdala LR. 2003. Chemosystematic interpretations of the flavonoids identified in Tagetes gracilis (Asteraceae). Biochem Syst Ecol, 31: 323325 . DOI: $10.1016 / \mathrm{S} 0305-$ 1978(02)00156-4.
Adehan SB, Biguezoton A, Adakal H, Assogba MN, Zoungrana S, Gbaguidi AM, Tonouhewa A, Kande S, Achi L, Kagone H, Adehan R, Mensah GA, de Deken R, Madder M, Farougou S. 2016. Acaricide resistance of Rhipicephalus microplus ticks in Benin. African Journal of Agricultural Research, 11(14): 11991208. DOI: 10.5897/ajar2015.10619.

Békro YA, Békro MJA, Boua BB, Tra Bi FH, Ehile EE. 2007. Etude ethnobotanique et screening phytochimique de Caesalpinia benthamiana (Baill.) Herend et Zarucchi (Caesalpiniaceae). Sciences et Nature, 4 : 217-225. DOI: 10.4314/scinat.v4i2.42146.

Broglio-Micheletti SMF, Valente ECN, Souza LA, Dias NS, Araújo AMN. 2009. Plant extracts in control of Rhipicephalus (Boophilus) microplus (Canestrini, 1887) (Acari: Ixodidae) in laboratory. Rev Bras de Parasitol Vétérinaire, 18 (4): 4448. DOI: 10.4322/rbpv.01804008.

Castro KN, Lima DF, Vasconcelos LC, Leite JR, Santos RC, Paz Neto AA, CostaJúnior LM. 2014. Acaricide activity in vitro of Acmella oleracea against Rhipicephalus microplus. Parasitol Res, 113(10): $\quad 3697-3701 . \quad$ DOI: 10.1007/s00436-014-4034-2.

Conceição SR, de Carneiro MM, Alves Reis IM, Branco A, Curcino Vieira IJ, BrazFilho R, Borges BM. 2017. In vitro acaricide activity of Ocotea aciphylla (Nees) Mez. (Lauraceae) extracts and identification of the compounds from the active fractions. Tiques Tick Borne Dis, 8(2): 275-282. DOI: 10.1016/j.ttbdis.2016.11.013.

Dantas AC, Machado DM, Araujo AC, Oliveira-Junior RG, Lima-Saraiva SR, Ribeiro LA, Almeida JR, Horta MC. 2015. Acaricidal activity of extracts from the leaves and aerial parts of Neoglaziovia variegata (Bromeliaceae) on the cattle tick Rhipicephalus (Boophilus) microplus. Res Vet Sci, 100: 165-168. DOI: 10.1016/j.rvsc.2015.04.012.

Diaha-Kouame ACA, Tian-Bi TYN, YAO KP, Achi YL, Dupraz M, Kouakou K, Dujardin JP. 2017. Apport de la morphométrie géométrique dans la lutte 
contre Rhipicephalus (Boophilus) microplus (Canestrini, 1888) sur le couloir de transhumance IvoiroBurkinabé. Int. J. Biol. Chem. Sci, 11(6): 2630-2648.

DOI: https://dx.doi.org/10.4314/ijbcs.v11i6.7.

Drummond DR, Ernest SE, Trevino JL, Gladney WJ, Graham OH. 1973. Boophilus annulatus and $B$. microplus: laboratory tests of insecticides. J Econ Entomol, 66 (1): 130. DOI: $10.1093 /$ jee/66.1.130.

Emilie V. 2011. Réactivité des polyéthers ionophores et des coumarines : vers des systèmes moléculaires efficaces pour la santé animale. Thèse de doctorat, Université de Lyon, France. p.197.

Fernández-Salas A, Alonso-Díaz MA, AcostaRodríguez R, Torres-Acosta JF, Sandoval-Castro CA, Rodríguez-Vivas RI. 2011. In vitro acaricidal effect of tannin-rich plants against the cattle tick Rhipicephalus (Boophilus) microplus .Vet Parasitol, 175(1-2): 113-118. DOI: 10.1016/j.vetpar.2010.09.016.

Furlong J. 2000. Booohilus microplus, la tique de bétail. pp. 17-33.

Godara NKS, Katoch RM, Katoch R, Anish Y, Parveen S, Bhavna VIJ, Varun K, Singh G. 2014. In Vitro Acaricidal Activity of Atropa belladonna and Its Components, Scopolamine and Atropine, against Rhipicephalus (Boophilus) microplus. The Scientific World Journal, $\mathrm{n}^{\circ} 713170$ : p.6. DOI: $10.1155 / 2014 / 713170$.

Godara R, Verma MK, Katoch R, Yadav A, Dutt P, Satti NK, Katoch M. 2018. In vitro acaricidal activity of Piper nigrum and Piper longum fruit extracts and their active components against Rhipicephalus (Boophilus) microplus ticks. Exp Appl Acarol, 75(3): $333-343 . \quad$ DOI: 10.1007/s10493-018-0268-5.

Grisi L, Leite RC, de Souza Martins JR, de Barros ATM, Andreotti R, Cançado PHD, de León AAP, Pereira JB, Villela HS. 2014. Reassessment of the potential economic impact of cattle parasites in Brazil. Rev. Bras. Parasitol. Vet, 23(2). DOI: http://dx.doi.org/10.1590/S198429612014042.
Héma MD, Biguezoton SA, Touré A, Konaté A, Koné M, Zoungrana S, Nébié C.H.R. 2018. Activité acaricide des extraits hexaniques et des huiles essentielles de quelques plantes aromatiques acclimatée au Burkina Faso sur la tique Rhipicephalus (Boophilus) microplus. Spécial hors-série $\mathrm{n}^{\circ} 4$, Sciences et techniques, Sciences naturelles et appliquées.

Kumar R, Nagar G, Sharma AK, Kumar S, Ray DD, Chaudhuri P, Ghosh S. 2012. Survey of pyrethroids resistance in Indian isolates of Rhipicephalus (Boophilus) microplus: identification of C190A mutation in the domain II of the parasodium channel gene. J. Acta Tropica, 125(2): 237-45. DOI: 10.1016/j.actatropica.2012.10.006.

Lebouvier N, Hue T, Hnawia E, Lesaffre L, Menut C, Nour M. 2013. Acaricidal activity of essential oils from five endemic conifers of New Caledonia on the cattle tick Rhipicephalus (Boophilus) microplus. Parasitol Res, 112(4): 137984. DOI: $10.1007 / \mathrm{s} 00436-012-3268-0$.

Nébié CHR. 2006. Etude des huiles essentielles de plantes aromatiques du Burkina Faso : Production, composition chimique et propriétés insecticides. Thèse de Doctorat unique, Université de Ouagadougou , Burkina Faso, P. 168.

Nitiema LW, Sombié PAED, Koala M, Del Fiore A. 2020. Phytochemical Composition and Antioxidant Activity of Balanites aegyptiaca, Securidaca longepedunculata and Acacia gourmaensis used against Seed-borne Fungi in Burkina Faso. Current Journal of Applied Science and Technology, 39(1): 79-87. DOI: 10.9734/cjast/2020/v39i130483.

Ouédraogo I, Sawadogo A, Nébié CHR, Dakouo D. 2016. Evaluation de la toxicité des huiles essentielles de Cymbopogon nardus $(L)$ et Ocimum gratissimum (L) contre Sitophilus zeamais Motsch et Rhyzopertha dominica $F$, les principaux insectes nuisibles au maïs en stockage au Burkina Faso. Int. J. Biol. Chem. Sci, 10(2): 695-705. DOI: 10.4314/ijbcs.v10i2.20. 
Parejo I, Jáuregui O, Viladomat F, Bastida J, Codina C. 2004. Characterization of acylated flavonoid-O-glycosides and methoxylated flavonoids from Tagetes maxima by liquid chromatography coupled to electrospray ionization tandem mass spectrometry. Rapid Commun Mass Spectrom, 18(23): 2801-2810. DOI: 10.1002/rcm.1697.

Parveen S, Godara R, Katoch R, Yadav A, Verma PK, Katoch M, Singh NK. 2014. In Vitro Evaluation of Ethanolic Extracts of Ageratum conyzoides and Artemisia absinthium against Cattle Tick, Rhipicephalus microplus. World Scientific Journal, n ${ }^{\circ}$ 858973: p.6. DOI: 10.1155/2014/858973.

Politi FAS, Figueira GM, Araújo AM, Sampieri BR, Camargo MMI, Szabó MPJ, Gervásio HB, Campaner SLD, Wagner $\mathrm{V}$ et Rosemeire CLR. Pietro. 2012. Acaricidal activity of ethanolic extract from aerial parts of Tagetes patula L. (Asteraceae) against larvae and engorged adult females of Rhipicephalus sanguineus (Latreille, 1806). Parasit Vecteurs, 5(1): 295. DOI: 10.1186/17563305-5-295.

Politi FAS, Fantatto RR, Da Silva AA, Moro IJ, Sampieri BR, Camargo-Mathias MI, Figueiredo A, De Souza A.C, Furlan M. 2019. Evaluation of Tagetes patula (Asteraceae) as an ecological alternative in the search for natural control of the cattle tick Rhipicephalus (Boophilus) microplus (Acari: Ixodidae). Exp Appl Acarol, 77(4): 601-618. DOI: 10.1007/s10493-019-00368-2.

Ramde-Tiendrebeogo A, Koala M, Ouattara N, Lompo M and Guissou IPA. 2019. A comparative study of phytochemical profile and antioxidant activity of Sahelian plants used in the treatment of infectious diseases in northern part of Burkina Faso: Acacia seyal Delile and Acacia tortilis (Forssk.) Hayne subsp. raddiana (Savi). Journal of Pharmacognosy and Phytotherapy, 11(3): 74-79. DOI: 10.5897/JPP2019.0555.
Sabatini GA, Kemp DH, Hughes S, Nari A, Hansen J. 2001. Tests to determine LC50 and discriminating doses for macrocyclic lactones against the cattle tick, Boophilus microplus. J.Vet Parasitol, 95: 53-62. DOI: 10.1016/s0304 4017(00)00406-4.

Santos FO, Lima HG, de Souza RS, Das Mercês NB, Serra TM, Uzeda RS, Reis IMA, Botura MB, Branco A, Batatinha MJM. 2018. In vitro acaricide and anticholinesterase activities of digitaria insularis (Poaceae) against Rhipicephalus (Boophilus) microplus. Vet Parasitol, 15(255): $\quad 102-106 . \quad$ DOI: 10.1016/j.vetpar.2018.04.003.

Silva LA, Milhomem MN, Santos MO, Arruda ACP, de Castro JAM, Fernandes YML, Maia JGS. 2017. Seasonal analysis and acaricidal activity of the thymol-type essential oil of Ocimum gratissimum and its major constituents against Rhipicephalus microplus (Acari: Ixodidae). Parasitol Res., 117(1): 59-65. DOI: $10.1007 / \mathrm{s} 00436-017-5662-0$.

Singh NK, Jyoti, Vemu B, Prerna M, Singh H, Dumka VK, Sharma SK. 2016. Acaricidal activity of leaf extracts of Dalbergia sissoo Roxb. (Fabaceae) against synthetic pyrethroid resistant Rhipicephalus (Boophilus) microplus. Res Vet Sci, 106: 1-6. DOI: 10.1016/j.rvsc.2016.03.002.

Tia EV, Cisse M, Douan GB, Kone A.2019. Etude comparée de l'effet insecticide des huiles essentielles de Cymbopogon citratus DC et d'Ocimum canum Sims sur Cylas puncticollis Boheman, un charançon de la patate douce. Int. J. Biol. Chem. Sci, 13(3): 1789-1799. DOI: https://dx.doi.org/10.4314/ijbcs.v13i3.46

Toure A, Komoin-Oka C, Sylla I. Cattle ticks population and prevalence of Babesia spp amongst it vector: Rhipicephalus (Boophilus) microplus in a zone of Ivory Coast. Int. J. Biol. Chem. Sci, 6(4): 15141581.

DOI: http://dx.doi.org/10.4314/ijbcs.v6i4.17.

Wagner, H. and Bladt, S. 1996. Plant drug analysis. A Thin Layer Chromatography. Atlas; (2nd Edn). Springer Ed: New York. 